\title{
Effectiveness of computer animation and geometrical instructional model on mathematics achievement and retention among junior secondary school students
}

\author{
Gambari, A. I. ${ }^{1}$, Falode, C. O. \& Adegbenro, D. A. \\ Science Education Department \\ Federal University of Technology, Minna \\ For correspondence: gambarii@futminna.edu.ng
}

\begin{abstract}
:
This study investigated the effectiveness of computer animation and geometry instructional model on mathematics achievement and retention on Junior Secondary School Students in Minna, Nigeria. It also examined the influence of gender on students' achievement and retention. The research was a pre-test post-test experimental and control group design. 40 junior secondary school students were drawn from two secondary schools within Minna metropolis. Stratified random sampling technique was used to select 40 students ( 20 males and 20 females). The Geometry Achievement Test (GAT) was used for data collection. The reliability coefficient of 0.87 was obtained using Kuder-Richardson (KR-20). GAT was administered to students as pre-test and post-test. The students' pretest and post-test scores were analyzed using t-test statistics. The results indicated that the students taught geometry using computer animation performed significantly better in posttest and retention test than their counterparts taught geometry using instructional model and conventional method respectively. However, there was no significant difference reported in the post-test performance scores of male and female students taught geometry using computer animation and instructional model respectively. These findings indicated that geometry concept in mathematics could be taught and learnt meaningfully through the use of computer animation.
\end{abstract}

Keywords: Computer Animation, Instructional Models; Geometry; Gender; Retention

\section{Introduction}

Mathematics has become the central intellectual discipline of all technological societies and it is indispensable in helping the individual to think more clearly about the values involved in this fast changing world (Abimbade \& Udousor, 1997). Fapohunda (2002) sees mathematics as an essential tool in the formation of the educated man. Its application in other disciplines, mostly in the sciences is appreciative and without it, knowledge of the sciences often remains superficial. In Nigeria, mathematics is taught as a core subject to all students at the primary and secondary school levels in order to give a sound basis for scientific and reflective thinking, and prepare them for the next level of education (FRN, 2004).

In spite of the importance and popularity of mathematics among Nigerian students, performance at junior secondary school level had been poor (Iwendi, 2012; NECO, 2012). Studies have shown that Nigerian students' achievement in secondary school mathematics has been relatively low over the years (Agwagah, 2000; Obodo, 2004; Osemwinyen, 2008; WAEC, 2011; \& Gimba, 2013).

Several factors have been attributed to the poor performance in secondary school mathematics, among which are: poor methods of teaching (Harbour-Peters, 2001), poor interest in mathematics (Badmus, 2002 \& Obodo, 2004), gender difference (Agwagah, 2000) and lack of appropriate instructional materials for teaching mathematics at all levels of education in Nigeria (Gambari, 2010). Various attempts have been made towards improving the low achievement and retention level of 
secondary school students in mathematics without any remarkable success (Gimba, 2006; Iwendi, 2009) Poor teaching method is one of the major factors influencing poor achievement and retention (Osemwinyen, 2009; Tolu, 2009).

Mathematics has several branches and some of these branches are more difficult for teachers to teach and students to learn than others. The basic geometry at junior secondary level serves as a background for understanding all branches of geometry at higher level. Research findings have confirmed that geometry is one of the topics among the abstract and complex aspects of mathematics, which students find difficult to learn, and some teachers find difficult to teach without the use of instructional materials (Akinlade, 2004 \& WAEC, 2011).

Instructional materials such as mathematical models have potentials in the teaching of abstract concepts such as geometry (Gambari \& Gana, 2005). Abimbade (1997) concluded that instructional models enhance visual imagery, stimulates learning and assists the teacher to properly convey the topic content to the learner, in order to achieve better understanding and performance.

In the review of empirical studies on instructional models, Shih, Kuo and Liu (2012) developed and evaluated the instructional model and learning system and found that the model enhanced mathematical achievement. Aboderin (1997) found that the use of Pythagoras model for mathematics instruction had positive effect on students' achievement. Joshua (2007) reported that using geometrical globe model for teaching mathematics at senior secondary schools enhanced students' performance. Also, Gimba (2006) and Gambari (2010) in different studies reported that using 3dimensional instructional model to supplement conventional teaching method produced higher achievement than the use of conventional instruction alone.

Computer has been used in the developed countries to tackle most of the teaching and learning challenges since 1980s. It has potential for arousing students' interest, motivation and achievement (Yusuf \& Afolabi, 2010). It can influence students' attitudes and interest towards mathematics which may positively affect their achievements and retention (Golden, McCrone, Walker \& Rudd, 2006). Computer-Assisted Instructional (CAI) package can be used to teach all subjects including sciences. According to Scott (2004) CAI can be used to provide opportunities for students to learn using drill and practice, tutorial, games and simulation activities, animation, and many others.

Animation is processed as a part of the visual information. There were two versions of the illustration mode, static and animated. The static version consisted of a graphic depicting the scientific process with no visual movement to show the process in operation, while the animated version showed the process with visual movement to demonstrate the process in operation. Animations have been defined as images in motion (Dwyer \& Dwyer, 2003). The capable features of Animation can enliven the learning experience. Animation which promotes flexibility of learning allowed a wider range of stimuli thus increased the student engagement in learning.

Animation seems to attract learners' attention and increase their motivation to learn. Many students get stimulated on a daily basis by computer animation then our instruction needs to contain computer animation (Martindale, 2007). Animation as an attention gaining strategy helps to reduce the processing demands in science, technology and mathematics (STM). As an elaboration strategy, it also facilitates encoding and retrieval processes by connecting information and providing alternative retrieval pathways (Gagne, 1985). Pavio's (1986) dual coding theory identified two separate information processing systems which is a visual system that processes visual knowledge, and a verbal system for processing verbal knowledge. According to Paivio (1986) and Riber (1994) animation that combines visual and verbal knowledge may store information into long-term memory thus facilitates encoding and retrieval process. 
Previous studies revealed that animation had facilitated the learner encoding process than static visuals (Lin, 2001). Rieber, Boyce and Assad (1990) suggested that animation helped decrease the time to retrieve information from long-term memory and then subsequently reconstruct it in short-term memory. Kearsley (2002) studies show that students who learn from animation have greater selfesteem and motivation. His studies also show that students may retain information and sustain the learning process increases. Mayer (1994) in his study showed that computer based animations can be used to promote scientific understanding. Finding also revealed that students performed better on recall and problem solving test when both the verbal and visual systems were utilized. Similarly, Westhoff, Bergman and Carroll (2010) reported that computer animations accompanied with traditional teaching increases the performance of high school biology students. In another study, Karacop and Doymus (2013) found that the teaching of chemical bonding via the animation and jigsaw techniques was more effective than the traditional teaching method in increasing academic achievement. In mathematics, Aktas, Bulut and Yuksel (2011) reported that academic performance of the students increased by using computer animations and activities about patterns. Similarly, Wang, Vaughn, and Liu (2011) found that animation interactivity improved students' performance in statistics. However, Palmiter and Elkerton (1993) studied the use of animation to aid computer authoring tasks, in their findings, Animation initially assisted both accuracy and speed, but after one week had elapsed, the subjects exposed to animations actually had regressed behind the nonanimation subjects.

Gender issues have been linked with performance of students in academic tasks in several studies but without any definite conclusion. Some studies revealed that male students performed better than females in science (Njoku, 2000). In a similar report, WAEC (1996-2011) chief examiners' reports confirmed that boys performed better than girls in mathematics. However, Spencer (2004), Osemmwinyen (2009) and Iwendi, (2012) found no gender difference in the performance of male and female students in school mathematics. Contrary to these reports, Kuruma (2004) and Gimba (2006) found that female students performed better than male students while exposed to geometry, mensuration and 3-dimensional mathematics instructional materials respectively.

Retention which is the ability to reproduce the learnt concept when the need arises has been researched by many researchers. However, Osemmwinyen (2009) found that students' interests and retention could be aroused and retained through the use of an appropriate instructional media like elearning. Bottge, Rueda, Serlin, Hung, Kwon (2007) found that students with learning disabilities retained what they had learned in mathematics several weeks after instruction, when exposed to Enhanced Anchored Instruction (EAI).

Generally, the relevance of geometry and subsequent difficulties experienced by students at junior secondary schools in Nigeria made a study on it pertinent. Moreover only few studies on computeranimation in mathematics and related areas at secondary education level were conducted in Nigeria. Especially, using computer animation with special features that enabled learners to visualize the 3D object, receive immediate feedback, self-paced learning, positive reinforcements, principles of mastery learning, associate learning and step by step learning among others. On these bases, this study examined the effectiveness of computer animation package and geometrical instructional model on the performance of junior secondary school students in mathematics.

\section{Purpose of the Study}

This study investigated the effectiveness of computer animation package and geometry instructional model on the achievement and retention of junior secondary schools students in mathematics. Specifically, the study examined the: 
(i) effectiveness of computer animation package (CAP), geometry instructional models (GIM) and traditional teaching method (TTM) on students' posttest and retention test,

(ii) influence of gender on the achievement of students taught geometry with computer animation package and geometry instructional model respectively,

\section{Research Hypotheses}

(i) There is no significant difference in the mean achievement scores of students exposed to geometry with CAP, GIM and TTM.

(ii) There is no significant difference in the mean achievement scores of male and female students taught geometry with CAP.

(iii) There is no significant difference in the mean achievement scores of male and female students taught geometry with GIM.

(iv) There is no significant difference in the mean retention scores of geometry students taught with CAP, GIM and TTM.

\section{Methodology}

This study adopted a pretest, posttest and delayed posttest design. Three levels of independent variable (two treatments and a control), two levels of gender (male and female) were investigated on students' achievements and retention in mathematics. Pretest was administered before the treatment and posttest, after four weeks of treatment, delayed posttest (retention test) was administered using Geometry Achievement Test (GAT).

The sample for the study was made up of 60 students, 30 male and 30 female students from three public co-educational junior secondary schools. The schools with common features (equivalent, composition, facilities, exposure) were sampled. The schools were randomly assigned to each of the experimental groups [computer animation package (CAP), geometric instructional model (GIM)] and control group (Traditional Teaching Method) (TTM). A stratified random sample of 60 students (10 males and 10 females) from each of the three schools was employed. Two treatments (CAP and GIM instruments) and one testing instrument (GAT) were employed for this study:

Computer Animation Package (CAP) consists of six topics in geometry: Cube; Cuboid; Cylinder; Cone; Sphere \& Hemisphere; and Pyramid. The necessity for researcher-made computer package was based on the fact that the commercially produced computer-animation packages are not common. Even, if they were available, they may not be directly relevant to the topic or objectives to be achieved in this study. As a result of this, developing a computer package for use by the researcher was inevitable.

The CAP was written in "Macromedia Dreamweaver 8" as the overall platform. Macromedia Flash utilizes the script symbolic instructional code (language) and animation that accommodates the interactive instructional process. Other computer programme and applications that were also utilized during the development process were Microsoft Word and Macromedia Fireworks 8. Macromedia Flash 8 was used for texts and graphics, Macromedia Fireworks also used for specific texts, graphics, and for buttons while Macromedia Flash was used for the Animation. The package consists of Introduction to the Package, General Preamble on Solid Geometry, Students' Registration, List of module as in 1,2,3,4,5 \& 6 and Click to Continue (Next Button) \& Click to go back (Previous Button). Each Module starts with objectives of the lesson. The interactivity features of CAP allowed students to navigate from one link to another. There are Home, Next, Back, click Animation, and Exit buttons in the contents and quiz pages. 


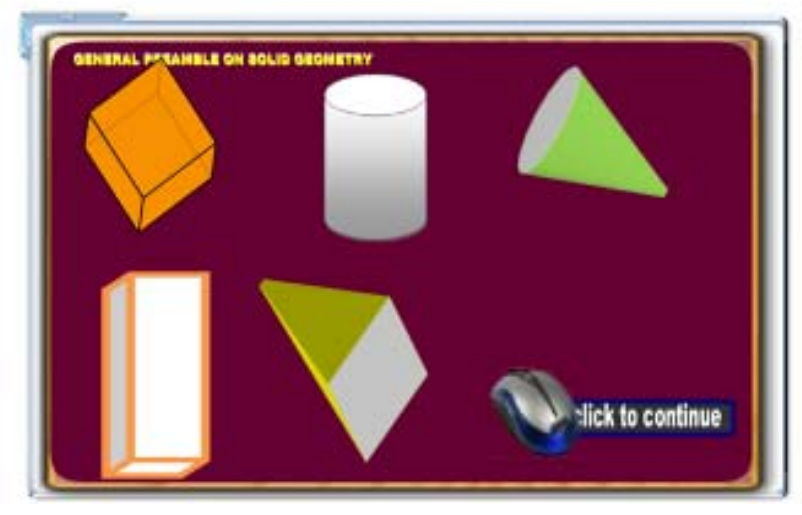

Fig. 1: General Introduction to Geometry

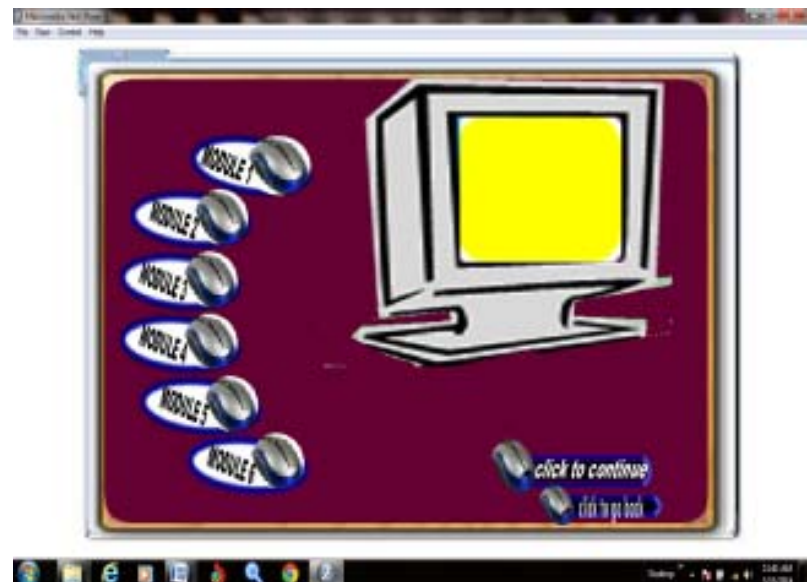

Fig. 2: List of Module

The production of the package was effected through a team of professionals and specialists including the programmer, computer operator, and the instructional designers (the researchers). ADDIE instructional development model was adapted in developing the package. This involves Analysis, Design, Development, Implementation and Evaluation stages of CAP.

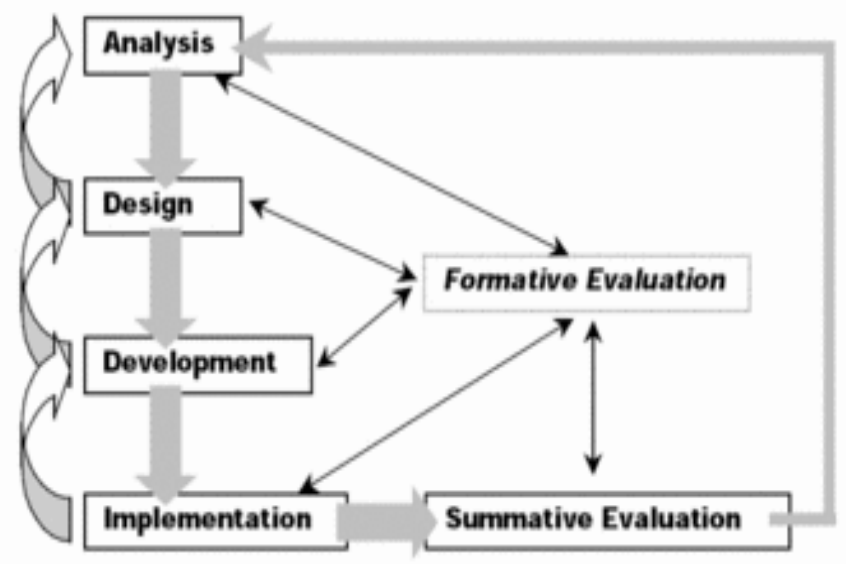

Discrem by. Steven J. MeCrif, lestructiend Syrtems, Colege of Bducatice, Pene State Oaverily

Fig. 3: ADDIE Model 
In the analysis stage, the instructional problem is clarified, the instructional goals and objectives are defined; the learning environment is identified; and a clear understanding of the "gaps" between the desired outcomes or behaviours and the learner's existing knowledge and skills is identified. At Design stage, the instructional designer deals with the selection of an instructional approach, learning objectives, assessment instruments, exercises, content, subject matter analysis, lesson planning and media selection. The design stage is systematic and specific. The development stage is where the Instructional Designers create and assemble the content assets (materials, resources, technologies, tests, etc.) that were created in the design stage. At this stage, CAP was developed and integrated. It was reviewed and revised according to the feedback given. Evaluation stage was conducted in two stages, formative was carried out in each stage of the ADDIE process, while, the summative evaluation determines the adequacy of the distributed materials in achieving the course objectives and provides opportunities for feedback from the users.

The CAP was validated by computer programmers and educational technology experts; subject content (mathematics) specialists; and finally field tested on sample representative similar to the students used for the final study. The corrected version of CAP with the geometry content was installed in the school computers. The computer presents information and displays animation to the learner on each of the units after which the students assessed themselves with objective questions at the end of each unit. The students could only proceed to the next unit, if they satisfactorily answered the questions. When a student fails a question, the computer package will give a remedial lesson on that particular concept or question until the student is able to master the concept, then he/she moves to the next unit. CAP displays each student scores and monitors his/her progress.

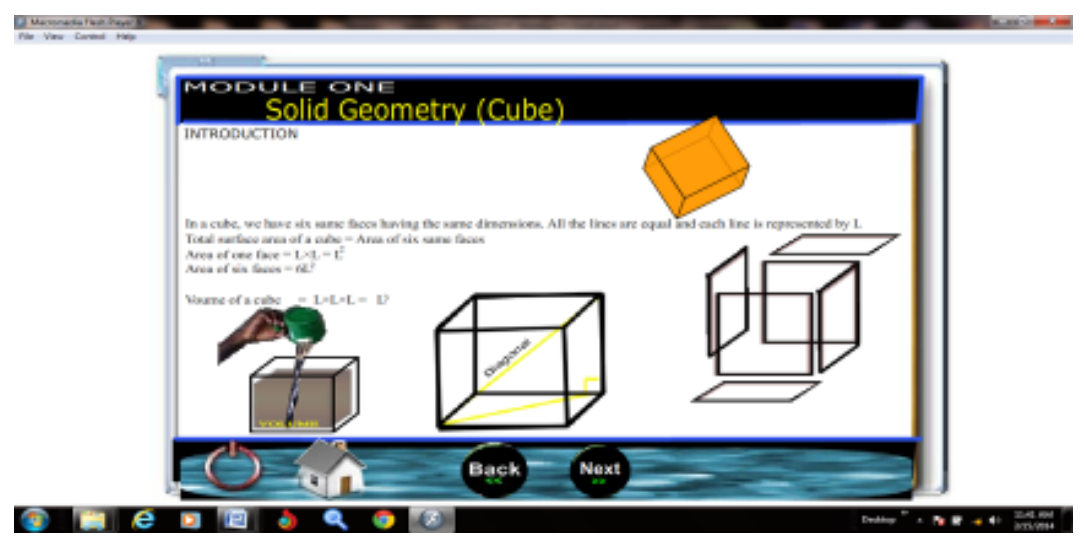

Fig. 4: Cube with Animation Display

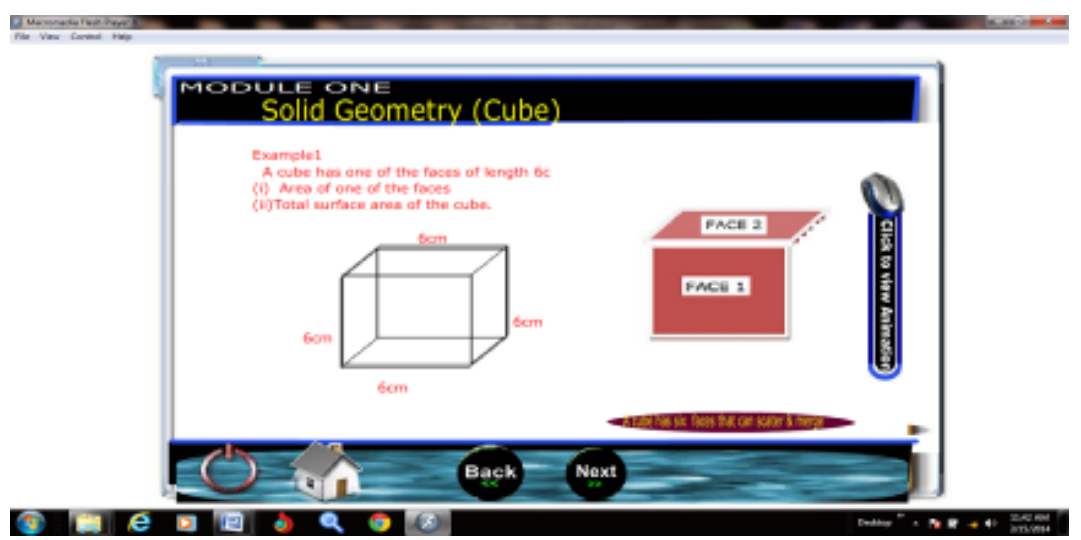

Fig. 5: Cube with worked example and Animation Display 


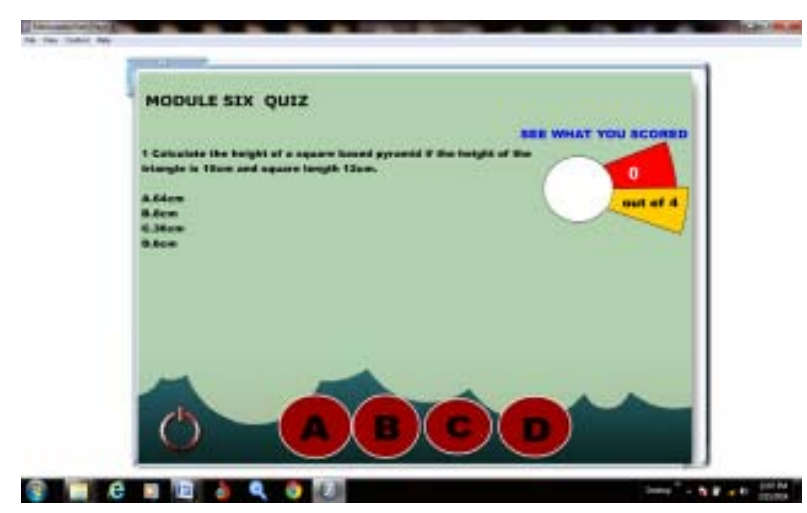

Fig. 6: Quiz Section

The GIM was designed to provide visual information covering the same topics and content in CAP specifically for junior secondary class II curriculum. The GIM was constructed using plywood to carve out the shapes of various geometrical objects. It was a three dimensional objects. The lesson was structured in such a way that students were allowed to touch and feel the objects. The instructional contents were taught followed by questions and answers related to instructional content. The GIM was validated by experts from educational technology and mathematics to determine the appropriateness of the materials. Their suggestions were used to improve the models.

Geometrical Achievement Test (GAT) was used in collecting data for this study. It consists of 40 multiple choice objective items with four options adopted from past examination of West African Examination Council (WAEC, May/June, 1988-2011) and National Examination Council (NECO, June/July, 2000-2011). The GAT was based on the contents of the CAP and GIM. Students were required to indicate their correct answers by ticking one of the letters (A - D) that corresponds to the correct option in each item. GAT was administered to the experimental and control groups as pre-test, posttest and again for the delayed posttest (retention test) after it had been reshuffled. On the scoring of the multiple-choice items, ' 1 ' mark was awarded for each correct answer and ' 0 ' for each wrong answer. The scores were converted to percentage. The test items were validated by experts in mathematics education and tested for reliability using 20 randomly selected JSII students outside the study area but within the population. The test was administered once on the pilot samples. A reliability test using the Kudar-Richardson (KR-20) revealed a reliability coefficient of 0.82 which was considered adequate for the research study.

\section{Results}

Geometry Achievement Test (GAT) was used as a pre-test for determining the academic levels of both experimental and control groups. Pre-test data for the groups were analyzed using One-way Analysis of Variance. The results of the analysis are presented in Table 1.

Table 1: $\quad$ ANOVA results of experimental and control groups

\begin{tabular}{llllll}
\hline $\begin{array}{l}\text { Sources of } \\
\text { Variation }\end{array}$ & $\begin{array}{l}\text { Sum of } \\
\text { Square }\end{array}$ & $\mathbf{d f}$ & Mean Square & F-value & p-value \\
\hline Between groups & 11.433 & 2 & 5.717 & & \\
Within Group & 381.150 & 57 & 6.687 & $0.855^{\text {ns }}$ & 0.431 \\
Total & 392.583 & 59 & & & \\
\hline
\end{tabular}

ns $=$ not significant $\mathrm{P}>0.05$ 
Table 1 shows one-way ANOVA results of students taught geometry using geometry instructional model, computer animation package and traditional teaching method. From table 1, the results revealed that there was no significant difference in the mean achievement scores of students in the three groups $\left(\mathrm{F}_{\mathrm{cal}}=0.855 ; \mathrm{df}=59, \mathrm{p}=0.431\right)$. This indicates the three groups are academically equivalent before the experiment started.

Hypothesis One: There is no significant difference in the achievement scores of students exposed to geometry with CAP, GIM and TTM.

To test this hypothesis, one-way ANOVA was employed as shown in Table 2A.

Table 2A: ANOVA results of experimental groups and control group

\begin{tabular}{llllll}
\hline $\begin{array}{l}\text { Sources of } \\
\text { Variation }\end{array}$ & $\begin{array}{l}\text { Sum of } \\
\text { Square }\end{array}$ & $\mathbf{d f}$ & $\begin{array}{l}\text { Mean } \\
\text { Square }\end{array}$ & F-Calculated & p-Value \\
\hline Between groups & 3348.933 & 2 & 1674.467 & & \\
Within Group & 1490.800 & 57 & 26.154 & $64.022^{*}$ & 0.000 \\
Total & 4839.733 & 59 & & & \\
\hline
\end{tabular}

*Significant at $\mathrm{P}<0.05$

Table 2A shows ANOVA results of the mean achievement scores of students in the experimental and control groups. The results revealed that there was significant difference in the mean achievement scores of students in the three groups $\left(\mathrm{F}_{\mathrm{cal}}=64.022, \mathrm{df}=59, \mathrm{p}=0.000\right)$. On this basis, hypothesis one is rejected. Therefore, the achievement scores of students exposed to CAP, GIM, and TTM instructional methods differed significantly.

To determine the location of the significant difference between the three groups, Scheffe's post-hoc test was conducted on the data. The result is shown in Table 2B.

Table 2B: Scheffe's post-hoc analysis of the groups means scores

\begin{tabular}{lllll}
\hline Groups & $\begin{array}{l}\text { Mean } \\
\text { Scores }\end{array}$ & $\begin{array}{l}\text { Group I } \\
(\mathrm{CAP})\end{array}$ & $\begin{array}{l}\text { Group II } \\
(\mathrm{GIM})\end{array}$ & $\begin{array}{l}\text { Group III } \\
(\mathrm{TTM})\end{array}$ \\
\hline Group I (CAP) & 73.20 & & ${ }^{*} 0.000$ & ${ }^{*} 0.000$ \\
Group II (GIM) & 64.10 & ${ }^{*} 0.000$ & & ${ }^{*} 0.000$ \\
Group III (TTM) & 54.90 & ${ }^{*} 0.000$ & ${ }^{*} 0.000$ & \\
\hline
\end{tabular}

* The mean difference is significant at the 0.05 level.

The data in Table 2B indicates that there was significant difference in the posttest mean scores of students exposed to CAP $(X=73.33)$ and those exposed to GIM $(X=64.10)$ in favour of experimental group I (CAP). It also indicates that significant difference exists in the posttest scores of students exposed to GIM (X=64.10) and those exposed to TTM (54.90) in favour of experiment group II (GIM). Also, significant differences was established in the posttest scores of students exposed to CAP $(X=73.20)$ and those exposed to TTM $(X=54.90)$ in favour of CAP group.

Hypothesis Two: There is no significant difference in the mean achievement scores of male and female students taught geometry with CAP.

To test this hypothesis, t-test statistic was employed and the result is presented in table 3. 
Table 3: t-test results on gender (experimental group I)

\begin{tabular}{llccccc}
\hline Variable & $\begin{array}{l}\text { Number of } \\
\text { sample }\end{array}$ & $\mathbf{d f}$ & $\begin{array}{l}\text { Mean } \\
(\mathbf{X})\end{array}$ & SD & $\mathbf{t}$-value & p-value \\
\hline Male & 10 & 18 & 73.20 & 4.517 & $1.216^{\mathrm{ns}}$ & 0.240 \\
& & & 71.30 & 2.003 & & \\
Female & 10 & & &
\end{tabular}

ns = not significant $\mathrm{P}>0.05$

Table 3 revealed that the mean achievement scores for male and female students taught geometry with CAP (Group I) are 73.20 and 71.80 respectively. The mean achievement scores for male did not differ significantly from that of the female counterparts when both groups were exposed to geometry using computer simulation package $\left(\mathrm{t}_{\mathrm{cal}}=1.216, \mathrm{df}=18, \mathrm{p}=0.240\right)$. On this basis, hypothesis 2 is not rejected. Therefore, there was no significant difference between the mean achievement scores of male and female students taught geometry with CAP.

Hypothesis Three: There is no significant difference in the mean achievement scores of male and female students taught geometry with GIM.

To test this hypothesis, t-test statistic was employed. The result is presented in table 4 .

Table 4: t-test results on gender (GIM)

\begin{tabular}{lllllll}
\hline Variable & $\begin{array}{l}\text { Number } \\
\text { sample }\end{array}$ & & $\begin{array}{l}\text { Mean } \\
(\mathbf{x})\end{array}$ & SD & t-value & P-value \\
\hline Male & 10 & & 64.60 & 6.240 & & \\
& & 18 & & & 0.719 ns & 0.482 \\
& & & & & & \\
Female & 10 & & 62.60 & 6.204 & & \\
ns $=$ not significant $\mathrm{P}>0.05$ & & & &
\end{tabular}

Table 4 shows t-test results of male and female students taught with geometric instructional model (GIM). The mean achievement scores for male and female students are 64.60 and 62.60 respectively. The mean achievement scores for male did not differ significantly from the female ( $t_{\text {cal }}=0.719, \mathrm{df}=18$, $p=0.482$ ). On this basis, hypothesis three was not rejected. Therefore, there is no significant difference between the mean achievement scores of male and female students taught geometry with GIM.

Hypothesis Four: There is no significant difference in the mean retention scores of geometry students taught with CAP, GIM and TTM.

Table 5: ANOVA results on CAP, GIM and TTM

\begin{tabular}{|c|c|c|c|c|c|}
\hline $\begin{array}{l}\text { Sources } \\
\text { Variation }\end{array}$ & Sum of Square & df & $\begin{array}{l}\text { Mean } \\
\text { Square }\end{array}$ & F-value & P-value \\
\hline Between groups & 3524.700 & 2 & 1762.350 & & \\
\hline Within Group & 1834.550 & 57 & 32.185 & $54.757^{*}$ & 0.000 \\
\hline Total & 5359.250 & 59 & & & \\
\hline
\end{tabular}

*Significant at $\mathrm{P}<0.05$ 
Table 5 shows ANOVA results of mean retention scores of students exposed to CAP, GIM and TTM groups. From the table, the results revealed significant difference among students exposed to GAP, GIM and TTM $\left(\mathrm{F}_{\mathrm{cal}}=54.575 ; \mathrm{df}=59, \mathrm{p}=0.000\right)$. On this basis, hypothesis four was rejected. Therefore, this implies that significant difference exist in the mean retention scores of junior secondary students taught geometry with CAP, GIM and CTM.

To determine the direction of the significant difference between the three groups, Scheffe's post-hoc test was conducted on the data. The result is shown in Table 6.

Table 6: Scheffe's post-hoc analysis of the groups mean scores

\begin{tabular}{lllll}
\hline Groups & $\begin{array}{l}\text { Mean } \\
\text { Scores }\end{array}$ & $\begin{array}{l}\text { Group I } \\
(\mathrm{CAP})\end{array}$ & $\begin{array}{l}\text { Group II } \\
(\mathrm{GIM})\end{array}$ & $\begin{array}{l}\text { Group III } \\
(\mathrm{TTM})\end{array}$ \\
\hline Group I (CAP) & 70.40 & & $0.000^{*}$ & $0.000^{*}$ \\
Group II (GIM) & 60.20 & $0.000^{*}$ & & $0.000^{*}$ \\
Group III (TTM) & 51.65 & $0.000^{*}$ & $0.000^{*}$ & \\
\hline
\end{tabular}

* The mean difference is significant at the 0.05 level.

The data in Table 6 indicates that there was significant difference in the posttest mean retention scores of students exposed to CAP $(X=70.40)$ and those exposed to GIM $(X=60.20)$ in favour of experimental group I (CAP). It also indicates that significant difference exists in the posttest scores of students exposed to GIM (X = 60.20) and those exposed to TTM (51.65) in favour of experiment group II (GIM). Also, significant difference was also established in the delayed posttest mean scores of students exposed to CAP $(X=70.40)$ and those exposed to TTM $(X=51.65)$ in favour of CAP group.

\section{Discussion}

The results of hypothesis one reveals that there is significant difference in the students achievements in favour of the group taught with geometrical concepts with computer animation. This results agreed with findings of (Lin, 2001), Mayer (1994), Westhoff, Bergman \& Carroll (2010), Karacop and Doymus (2013), Aktas, Bulut and Yuksel (2011), and Wang, Vaughn, and Liu (2011) which in their previous studies found that students taught using computer animation performed better than their counterparts taught with any other teaching methods. The superiority of computer animation to other methods may be attributed to several factors, some of which are learners' ability to visualize the 3D object, receive immediate feedback, self paced learning, reinforcement, principles of mastery learning, associate learning and step by step learning among others. Furthermore, Animation facilitates learner encoding process, greater self-esteem and motivation (Lin, 2001 \& Kearsley, 2002). All these are attributes of computer animation package makes it a unique instructional tool.

The finding on students taught with geometry instructional model having superiority over the traditional teaching method, this could be attributed to the assertion of Abimbade (1997) who said that instructional model enhances visual imagery, stimulates learning and assists the teacher to properly convey the topic content to the learners to achieve better performance. The findings support the earlier findings of Aboderin (1997), Gimba (2006) and Joshua (2007) who reported that the use of Pythagoras model for mathematics instruction, 3-dimesional instructional model for mathematics and geometrical globe instructional model for teaching mathematics at senior secondary schools enhanced students academic performance.

The results of hypotheses two and three shows that there is no gender effect on the achievement of male and female students taught geometrical concepts with CAP and GIM. This implies that irrespective of the instructional methods, male and female students benefitted equally. This result 
differed with the findings of Njoku (2000), WAEC, chief examiners' report (2011) which revealed that boys performed better than girls in mathematics. It also disagrees with the findings of Kuruma (2004) and Gimba (2006) who reported that female students performed better than male students when exposed to geometry, mensuration and 3-dimensional mathematics instructional materials respectively. In another study, Anagbogu and Ezelioras' (2007) revealed that female students performed better than males in science process skills. Meanwhile, this finding is in agreement with the results of Etukudo (2003) Spencer (2004), Osemmwinyen (2009) and Iwendi, (2012) who found that there is no statistically significant difference between male and female students taught mathematics. One factor which is said to distinguish male from female in their achievement in science is the presence of mathematics. Even then, Maccoby (1970) has noted that between the ages 7, 11, and 12 , males and females perform about equally in skills connected with arithmetic computation. The test contained little or no mathematics. Therefore, the finding that both male and female students in this study performed evenly is not misleading.

The results of hypothesis four reveals that there is significant difference in the delayed posttest of three groups in favour of the group taught geometrical concept with computer animation. The results supported the earlier findings of Golden, McCrone and Ruud (2006) and Bottge, Rueda, Serlin, Hung, Kwon (2007). However, this differs to the findings of Birgan (2010) who reported that there was no difference in retention rates among students who utilized computerized homework and those who did not. The superiority of this finding could be deduced from Lin (2001), Kearsley (2002) and Osemwinyen's (2009) that Animation facilitates learner encoding process, greater self-esteem and motivation.

\section{Conclusion}

The study has examined the poor performance in mathematics education especially within the secondary school level in a rapidly technology changing world. The innovative technology using computer animation package for teaching mathematics seems to be the answer to the poor performance problem. Computer animation package was more effective in teaching the mathematical concept of geometry, improved learners' performance, enhanced their retention, and is also gender friendly.

\section{Recommendations}

Based on the findings of this study, the following recommendations are made.

(i) Computer animation package was found to be effective as a teaching strategy for geometry instruction when compared with instructional models and traditional method of instruction. Therefore, mathematics teachers should be encouraged to use it.

(ii) Male and female students were affected positively and evenly by the use of computer animation package. Therefore, mathematics teachers should employ this strategy to improve male and female students' achievement and retention in mathematics at junior secondary school level in particular and other levels in general.

(iii) Geometry instructional model was also found effective as a teaching strategy for geometry instruction as compared to traditional teaching method. Teachers should use instructional model for teaching geometry concept if they could not develop computer animation package or where there is no power supply.

(iv) It is an interesting and useful experience to improvise using local resources for teaching some units of mathematics at junior secondary school level. Mathematics teachers should improvise instructional material to teach abstract concepts in mathematics in order to improve students' understanding. 


\section{References}

Abimbade, A (1997). Principle and practice of educational technology. Ibadan: International Publishers Ltd.

Abimbade, A. \& Udousoro, U. J. (1997). The place of computer-assisted instruction in mathematics education. In Olrenwaju, A. (ed). Proceeding of Ajumogbobia Memoria Conference 1997 (40 th Annual Conference of STAN) UNESCO, Pp. $238-243$.

Aboderin, G. S. (1997). Construction of Pythagoras model for mathematics instruction in secondary schools. Unpublished B.Tech Project, Department of Science Education, FUT Minna.

Agwagah, U. N. V. (2000). Influence of gender difference of students in their achievement in secondary school mathematics. Abacus, 25(1), 102-112.

Aktas, M., Bulut, M \& Yuksel T. (2011). The effect of using computer animations and activities about teaching patterns in primary mathematics. The Turkish Online Journal of Educational Technology, 10(3), 273-277.

Akinlade, C. R. (2004). Computer in teaching mathematics. Ibadan: University Press Ltd.

Anagbogu, M. A. \& Ezeliora, B. (2007). Sex differences and scientific performance. Women Journal of Science and Technology. 4 , 10-20.

Araromi, M. A. (1998). Effect of visual imagery instruction on achievement in language with particular reference to French in Nigeria. Nigeria. Journal of Curriculum Studies, 21, 14.

Badmus, G. A. (2002). Interest and attitude as correlated of mathematics achievement of secondary school students. npublished Paper, Faculty of Education, Uniben.

Baki, A. Kosa, T. Guven, B. (2011). A comparative study of the effects of using dynamic geometry software and physical manipulative on the spatial visualization skills of pre-service mathaematics teachers. British Journal of Educational Technology, 42(2), 291-310.

Birgan, L. J. (2010). The effects of multimedia technology on students' perceptions and retention rates in mathematics at a community college. Dissertation, Northcentral University.

Bottge, B. A. Rueda, E. Serlin, R. C. Hung, Y. Kwon, J. (2007). Shrinking achievement differences with anchored math problems: Challenges and possibilities. Journal of Special Education, 41(1), 31-49.

Dwyer, F. \& Dwyer, C. (2003). Effect of animation in facilitating knowledge acquisition. Paper Presented at the Meeting of Pennsylvania Educational Research Association, Hershey, PA.

Etukudo, U. E. (2003). The effects of formula approach on the performance of senior secondary school students in mathematics. Abacus, 28(1), 8-12.

Ezekoka, G. K. (2010). Effect of gender on the use of computer in the teaching learning process in Nigerian school systems. Minna: $31^{\text {st }}$ National Education Association and Media Technology (NEAMT), Annual Convention and National Conference.

Fapohunda, O. M. (2002). Educational computing: Learning with tomorrow's technologies. Ibadan: University Press.

FRN (2004). National policy on education. Lagos: NERDC Press.

Gagne, R.M. (1985). The conditions of learning. New York: Holt, Rinehart and Winston.

Gambari, A. I. (2010). Effect of instructional models on the performance of junior secondary school students in geometry in Minna, Nigeria. Delsu Journal of Educational Research and Development, 9(1), 54-65.

Gimba, R. W. (2006). Effects of 3-dimensional instructional materials on the teaching and learning of mathematics among senior secondary schools in Minna metropolis. 2nd SSSE Annual National Conference, Federal University of Technology, Minna. Held between $19^{\text {th }}-2^{\text {nd }}$ November, 2006.

Gimba, R. W. (2013). Effects of computer package on achievement, retention and interest in set theory among secondary school students in Niger state. Unpublished Ph.D thesis, University of Nigeria, Nsukka.

Golden, S., McCrone, T. \& Ruud, P. (2006). Impact of e-learning in further education: Survey of scale and breadth. (Online). Available: http://www.dfes.giv.uk/research/data/uploadfiles/RR745.pdf

Harbour-Peters, V. F. A. (2001). Noteworthy points on measurement and evaluation. Enugu: Swaap Press Ltd.

Iwendi, B. C. (2012). Effects of gender and age on the mathematics achievement of secondary school students in Minna metropolis, Nigeria. JOSTMED, 9(1), 215-223. Available online: http:/www.jostmed.com

Joshua, F. (2007). Design and construction of geometrical model for learning mathematics in the senior secondary schools. Unpublished B.Tech.project, Science Education Department, Federal University of Technology, Minna.

Karacop, A. \& Doymus, K. (2013). Effects of jigsaw cooperative learning and animation techniques on students' understanding of chemical bonding and their conceptions of the particulate nature of matter. Journal of Science Education and Technology, 22(2), 186-203.

Kearsley, G. (2002). Exploration in learning \& instruction: The theory into practice. Database (Online).

Kiboss, J. K. (2012). Effects of special e-learning program on hearing-impaired learners' achievement and perceptions on basic geometry in lower primary mathematics. Journal of Educational Computing Research, 46(1), 31-59.

Kurumeh, M. S. C. (2004). Effect of ethno-mathematics teaching approach on students achievement and interest in geometry and mensuration. Unpublished Ph.D thesis, University of Nigeria Nsukka.

Lin, C.H. (2001). The effect of varied enhancements to animated instruction on test measuring different educational objectives. Unpublished Doctoral Dissertation, The Pennsylvania State University.

Martin, P. \& Velay, J. (2012). Do computer improve the drawing of a geometrical figure for 10 year-old children? International Journal of Technology and Design Education, 22(1), 13-23.

Martindale, G. (2007, November 21). Know your learning style. Message posted to http://www.stateuniversity.com/blog/permalink/Know-Your-Learning-Style.html 
National Examination Council (NECO). (2012). Chief examiner's report. Njoku, Z. C. (2000). Gender and acquisition of science process skills among secondary school students: Implication for science and teaching. $42^{\text {nd }}$ annual conference proceeding of STAN $(206-209)$.

Obodo, G. C. (2004). Principles and practices of mathematics education in Nigeria. Enugu: Floxtone Press.

Osemwinyen, A. C. (2009). Effects of e-learning on retention and achievement in secondary school mathematics in Abuja, Nigeria. Unpublished Ph.D thesis, University of Nigeria, Nsukka.

Palmiter, S. (1993). The effectiveness of animated demonstrations for computer-based tasks: A summary, model, and future research. Journal of Visual Languages and Computing, 4(1), 71-89.

Pavio, A. (1986). Mental representations: A dual coding approach. Oxford, England. Oxford University Press.

Riber, L.P. (1994). Computer, graphics and learning. Madison, Wisconsin: Brown \& Benchmark Publishers.

Riber, L. P, Boyce, M. J. \& Assad, C. (1990). The effect of computer animation on adult learning and retrieval task. Journal of Computer-based Instruction, 17(2).

Shih, S, Kuo, B, Liu, Y. (2012). Adaptively ubiquitous learning in campus math path. Educational Technology \& Society, 15(2), 298308.

Spencer, D. J. (2004). Engagement with mathematics courseware in traditional and online learning environments: Relationship to motivation, achievement, gender, and gender orientation. Unpublished Ph.D dissertation submitted to the Faculty of Graduate School of Emory University. Retrieved March 17, 2007, from http://www.dcs.emory.edu/mfp/Spencer Dissertation2004.pdf.

Tolu, O. T. (2009). Effects of computer animation and instruction model on the Performance of students in senior secondary students biology in Minna, Niger State, Nigeria. Unpublished Bachelor of Technology, (B, Tech) Project, Department of Science Education, Federal University of Technology, Minna, Nigeria

Wang, P, Vaughn, B.K. \& Liu, M. (2011). The impact of animation interactivity on novices' learning of introductory statistics. Computer \& Education, 56(1), 300 - 311.

West African Examination Council (WAEC) (2011). West African senior secondary school certificate examination May/June Chief examiner's report. WAEC: Lagos.

Westhoff, B. W., Bergman, D. \& Carroll, J. (2010). The effects of computer animations on high school students performance and engagement in biology. Proceedings of the 6th Annual GRASP Symposium, Wichita State University, 2010.

Yusuf, M. O. \& Afolabi. A. O. (2010). effects of computer assisted instruction (CAI) on secondary school students' performance in biology. Turkish Online Journal of Educational Technology 9(1). Available online at www.tojet.com 


\section{APPENDIX A}

\section{GEOMETRY ACHIEVEMENT TEST [GAT] SECTION A}

\section{Introduction}

The purpose of this question paper is to collect information which will be used in a research study to improve the teaching and learning of physics at senior secondary school level. Every information you give is, therefore, strictly for academic purpose and will be treated confidentially. Your name is NOT required.

\section{Instructions}

(i) Please read the questions or statements very carefully and respond appropriately.

(ii) Choose the most appropriate alternative from the options A to E given for each item.

(iii) Shade only one answer for each question.

(iv) Attempt all the questions

(v) Respondents are free to ask questions on any of the items that need clarification.

(vi) Erase any incorrect answer properly before choosing another option

(viii) Use pencil only.

(ix) Time allowed: 60 minutes

\section{Bio-Data}

Male

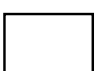

Female

NAME OF SCHOOL:

CLASS:

DATE:

\section{SECTION B}

MULTIPLE CHOICE OBJECTIVE TEST

1. A solid shape which has a circular face and a curved surface is known as ....
(A). A Cube
(B). Rectangle
(C). Cylinder
(D). Cone

2. With the aid of the diagram below, identify the formula of a curved surface area of a Cone
(A). $\pi \mathrm{rL}$
(B). $\quad \pi r^{2} h$
(C). $\pi \mathrm{rh}$
(D). $\pi \mathrm{rL}^{2}$

3. The total curved surface
(A). $\quad \pi \mathrm{rh}+\pi \mathrm{r}^{2}$
(B). $\quad \pi \mathrm{r}(\mathrm{L}+\mathrm{r})$
(C). $\pi r^{2} L+\pi r$
(D). $\pi \mathrm{r}^{2} \mathrm{~L}$

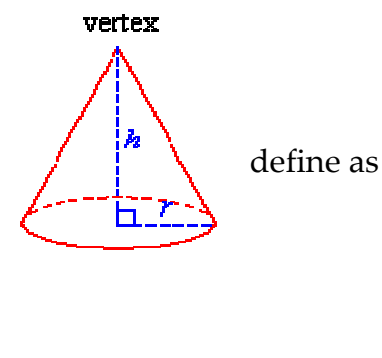

4. The curved surface area of a cylinder is define as
(A). $\quad 2 \pi(h+r)$
(B). $\quad 2 \pi r^{2}$
(C). $2 \pi \mathrm{rh}$
(D). $3 \pi \mathrm{rh}$

5. Which of the formulae is correct in determine the volume of a cylinder.

A. $\pi \mathrm{rh}$ 

B. $\pi r^{2} h$
C. $\pi \mathrm{r}$
D. $\pi \mathrm{rh}^{2}$

6. A point or corner where three (3) or more edges meet is called

A. Sharp point

B. Plane

C. Vertex

D. rectangle

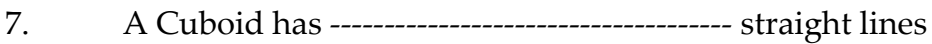
A. 4
B. 12
C. 8
D. 5

8. The formula used to calculate the volume of cuboid is
A. $\quad \mathrm{Lxw}$
B. $\quad W \times h$
C. $\quad 1 / 2 \mathrm{~W} \times \mathrm{h}$
D. Lxw

9. A Cube is a cuboid in which all faces are

A. Rhombus

B. Rectangle

C. Square

D. Cone.

10. The typical example of a cube is
A. Tin
B. Cylinder
C. An empty box of matches
D. A cube of sugar

11. The formula use to calculate the volume of a cube is
A. $\quad \mathrm{L}^{2}$
B. $\mathrm{L}^{3}$
C. L
D. $\mathrm{L}^{4}$

12. The formula use to find the area of a cube is
A. $6 \mathrm{~L}^{2}$
B. $4 \mathrm{~L}^{2}$
C. $2 \mathrm{~L}^{2}$
D. $\mathrm{L}^{2}$

13. Find the total surface area of the cube in the figure

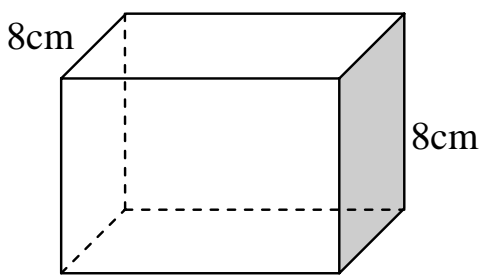
(A). $384 \mathrm{~cm}$
(B). $\quad 512 \mathrm{~cm}$
(C). $\quad 288 \mathrm{~cm}$
(D) $216 \mathrm{~cm}$ 
14. Calculate the diagonal of the cube shown in the figure below.
(A). $\quad 13.8 \mathrm{~cm}$
(B). $\quad 11.3 \mathrm{~cm}$
(C). $\quad 27.6 \mathrm{~cm}$
(D) $16.0 \mathrm{~cm}$

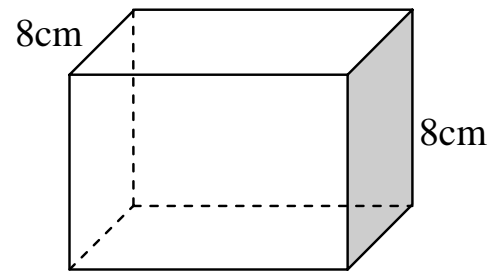

15. Calculate the volume of the cube shown in the figure below.
(A). $\quad 384 \mathrm{~cm}$
(B). $\quad 512 \mathrm{~cm}$
(C). $\quad 288 \mathrm{~cm}$
(D) $216 \mathrm{~cm}$

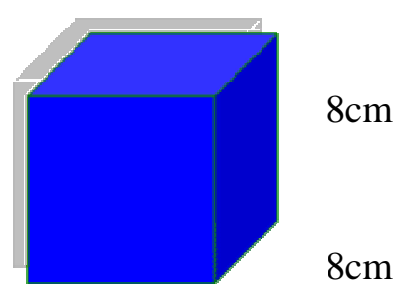

16. If the volume of a cube is $216 \mathrm{~cm}^{3}$, find the 1 lenty $8 \mathrm{~cm}$ us one side of the cube.
(A). $\quad 6 \mathrm{~cm}$
(B). $\quad 12 \mathrm{~cm}$
(C). $18 \mathrm{~cm}$
(D) $\quad 27 \mathrm{~cm}$

17. If the total surface area of a cube is $384 \mathrm{~cm}^{2}$, find the length of one of the faces.
(A). $\quad 0.8 \mathrm{~cm}$
(B). $\quad 8 \mathrm{~cm}$
(C). $\quad 18 \mathrm{~cm}$
(D) $28 \mathrm{~cm}$

18. Calculate the total surface area of a cuboid with dimensions $12 \mathrm{~cm}$ by $10 \mathrm{~cm}$ by $8 \mathrm{~cm}$.
(A). $\quad 528 \mathrm{~cm}$
(B). $\quad 376 \mathrm{~cm}$
(C). $\quad 296 \mathrm{~cm}$
(D) $692 \mathrm{~cm}$

19. Calculate the volume of a cuboid with dimensions $8 \mathrm{~cm}$ by $3 \mathrm{~cm}$ by $7 \mathrm{~cm}$.
(A). $\quad 118 \mathrm{~cm}$
(B). $\quad 156 \mathrm{~cm}$
(C). $168 \mathrm{~cm}$
(D) $180 \mathrm{~cm}$

20. Calculate the length of the diagonal in the figure below.
(A). $\quad 2.24 \mathrm{~cm}$
(B). $\quad 4.24 \mathrm{~cm}$
(C). $\quad 6.24 \mathrm{~cm}$
(D) $8.24 \mathrm{~m}$

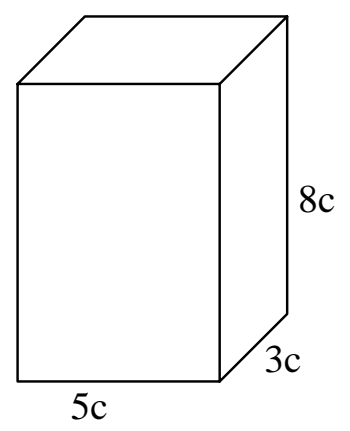


21. If the volume of a cuboid is given by $120 \mathrm{~cm}^{3}$, calculate the length of the cube if the breath and height are given as $5 \mathrm{~cm}$ and $3 \mathrm{~cm}$ respectively.
(A). $\quad 0.8 \mathrm{~cm}$
(B). $\quad 8.0 \mathrm{~cm}$
(C). $\quad 18.0 \mathrm{~cm}$
(D) $80.0 \mathrm{~cm}$

22. Calculate the height of a cuboid if the volume is $210 \mathrm{~cm}^{3}$ and the length and breadth are $5 \mathrm{~cm}$ and $7 \mathrm{~cm}$ respectively.
(A). $6 \mathrm{~cm}$
(B). $16 \mathrm{~cm}$
(C). $26 \mathrm{~cm}$
(D) $36 \mathrm{~cm}$

23. Find the curved surface area of the cylinder in figure below.
(A). $\quad 602.88 \mathrm{~cm}^{2}$
(B). $\quad 401.92 \mathrm{~cm}^{2}$
(C). $\quad 200.96 \mathrm{~cm}^{2}$
(D) $\quad 1004.80 \mathrm{~cm}^{2}$

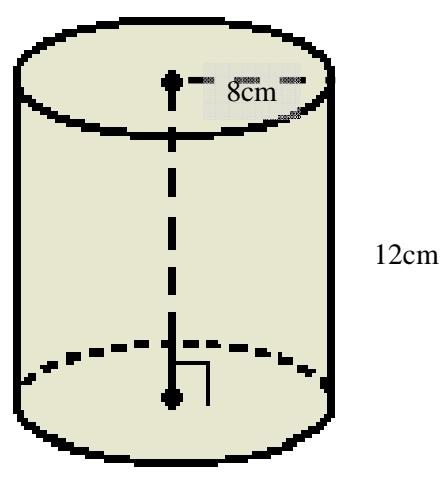

24. Calculate the volume of the cylinder in the figure below.
(A). $\quad 153.68 \mathrm{~cm}^{3}$
(B). $\quad 175.84 \mathrm{~cm}^{3}$
(C). $\quad 183.14 \mathrm{~cm}^{3}$
(D) $\quad 2411.52 \mathrm{~cm}^{3}$

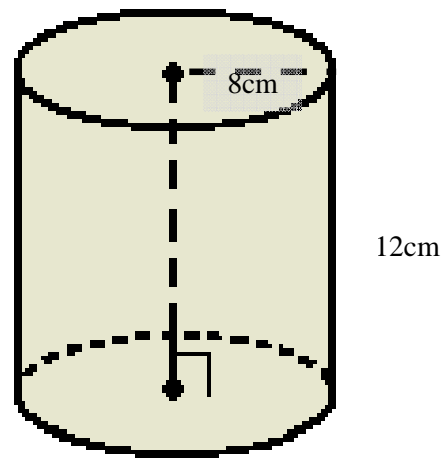

25. A cylindrical tank has its base radius of $3 \mathrm{~cm}$ and height of $7 \mathrm{~cm}$, calculate the total surface area.

(A). $\quad 188.40 \mathrm{~cm}^{2}$

(B). $\quad 198.44 \mathrm{~cm}^{2}$

(C). $\quad 208.14 \mathrm{~cm}^{2}$

(D) $\quad 218.52 \mathrm{~cm}^{2}$

26. A bucket in the form of a container has a volume of $1908.75 \mathrm{~cm}^{3}$, calculate the height of the container given that the base radius is $9 \mathrm{~cm}$.
(A). $\quad 170.55 \mathrm{~cm}$
(B). $\quad 75.50 \mathrm{~cm}$
(C). $\quad 17.54 \mathrm{~cm}$
(D) $7.50 \mathrm{~cm}$

27. Calculate the depth of a cylindrical whose capacity is $17325 \mathrm{~cm}^{3}$ if the base radius is $7 \mathrm{~cm}$.
(A). $\quad 112.5 \mathrm{~cm}$ 

(B). $\quad 102.5 \mathrm{~cm}$
(C). $\quad 12.5 \mathrm{~cm}$
(D) $\quad 11.2 \mathrm{~cm}$

28. A sector of a circle of radius $7 \mathrm{~cm}$ which subtends an angle of $75^{\circ}$ at the centre is used to form a cone, calculate the base radius of the cone.
(A). $1.92 \mathrm{~m}$
(B). $\quad 1.98 \mathrm{~m}$
(C). $1.89 \mathrm{~m}$
(D) $1.70 \mathrm{~m}$

29. A cone of base diameter $12 \mathrm{~cm}$ and slant height of $10 \mathrm{~cm}$, calculate the total surface area.

(A). $\quad 113.40 \mathrm{~cm}^{2}$

(B). $\quad 213.04 \mathrm{~cm}^{2}$

(C). $\quad 301.44 \mathrm{~cm}^{2}$

(D) $\quad 414.48 \mathrm{~cm}^{2}$

30. Calculate the volume of a cone of slant height $10 \mathrm{~cm}$ and base diameter $12 \mathrm{~cm}$.
(A). $\quad 904.32 \mathrm{~cm}^{3}$
(B). $\quad 804.34 \mathrm{~cm}^{3}$
(C). $\quad 708.14 \mathrm{~cm}^{3}$
(D) $\quad 608.52 \mathrm{~cm}^{3}$

31. Find the curved surface area of a cone of base radius $6 \mathrm{~cm}$ and slant height $10 \mathrm{~cm}$.
(A). $\quad 1884.04 \mathrm{~cm}^{2}$
(B). $\quad 188.40 \mathrm{~cm}^{2}$
(C). $\quad 18.84 \mathrm{~cm}^{2}$
(D) $8.18 \mathrm{~cm}^{2}$

32. Calculate the volume of a sphere with radius $9 \mathrm{~cm}$.

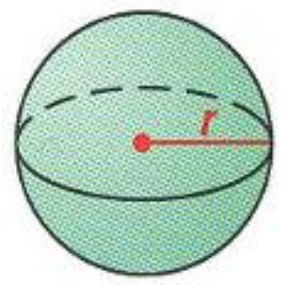
(A). $\quad 4156.24 \mathrm{~cm}^{3}$
(B). $\quad 3052.08 \mathrm{~cm}^{3}$
(C). $\quad 2017.36 \mathrm{~cm}^{3}$
(D) $\quad 1138.04 \mathrm{~cm}^{3}$

33. Calculate the surface area of a sphere with radius $11 \mathrm{~cm}$.
(A). $\quad 1512.64 \mathrm{~cm}^{2}$
(B). $\quad 1515.46 \mathrm{~cm}^{2}$
(C). $\quad 1519.76 \mathrm{~cm}^{2}$
(D) $\quad 1516.67 \mathrm{~cm}^{2}$

34. A sphere of radius $7 \mathrm{~cm}$ is cut into two equal parts, calculate the volume of one of the parts.

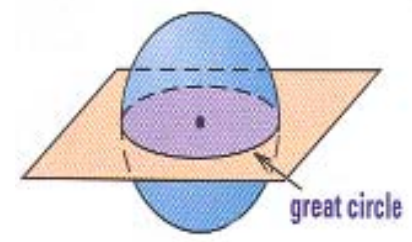



(A). $\quad 918.04 \mathrm{~cm}^{3}$
(B). $\quad 718.01 \mathrm{~cm}^{3}$
(C). $\quad 518.06 \mathrm{~cm}^{3}$
(D) $\quad 418.08 \mathrm{~cm}^{3}$

35. A hemisphere of radius $14 \mathrm{~cm}$, calculate its surface area in terms of $\pi$.
(A). $588 \pi$
(B). $438 \pi$
(C). $328 \pi$
(D) $218 \pi$

36. A sphere has a radius of $8 \mathrm{~cm}$, find the surface area and volume.

(A). $\quad 703.54 \mathrm{~cm}^{2} ; 3143.75 \mathrm{~cm}^{3}$

(B). $\quad 613.44 \mathrm{~cm}^{2} ; 4234.72 \mathrm{~cm}^{3}$

(C) $\quad 523.41 \mathrm{~cm}^{2} ; 5334.78 \mathrm{~cm}^{3}$

(D). $\quad 803.84 \mathrm{~cm}^{2} ; 2143.57 \mathrm{~cm}^{3}$

37. Calculate the height of a square based pyramid if the height of the triangle is $10 \mathrm{~cm}$ and square length $12 \mathrm{~cm}$.

(A). $\quad 64 \mathrm{~cm}$

(B). $\quad 36 \mathrm{~cm}$

(C). $\quad 18 \mathrm{~cm}$

(D) $8 \mathrm{~cm}$

38. Calculate the total surface area of the pyramid in the figure shown below.
(A). $\quad 384 \mathrm{~cm}^{2}$
(B). $\quad 284 \mathrm{~cm}^{2}$
(C). $\quad 240 \mathrm{~cm}^{2}$
(D) $144 \mathrm{~cm}^{2}$

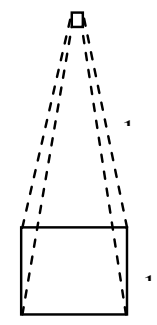

39. A rectangular based pyramid of base dimension $12 \mathrm{~cm}$ by $10 \mathrm{~cm}$ has a height of $8 \mathrm{~cm}$, calculate the volume of the pyramid.
(A). $\quad 240 \mathrm{~cm}^{3}$
(B). $320 \mathrm{~cm}^{3}$
(C). $\quad 420 \mathrm{~cm}^{3}$
(D) $528 \mathrm{~cm}^{3}$

40. A right pyramid consists of a square base side $13 \mathrm{~cm}$ and four isosceles triangles whose equal sides are $27 \mathrm{~cm}$ each, calculate the total surface area and volume of the pyramid.
(A). $\quad 754 \mathrm{~cm}^{2} ; 2437 \mathrm{~cm}^{3}$
(B). $\quad 845 \mathrm{~cm}^{2} ; 1430 \mathrm{~cm}^{3}$
(C). $\quad 645 \mathrm{~cm}^{2} ; 3430.72 \mathrm{~cm}^{3}$
(D) $545 \mathrm{~cm}^{2} ; 4430 \mathrm{~cm}^{3}$

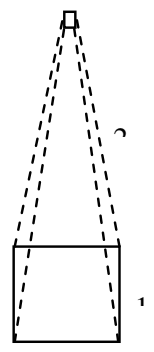


APPENDIX B

\section{KEY TO THE ANSWER}

1. D

2. A

3. B

4. C

5. B

6. $\mathrm{C}$

7. B

8. D

9. C

10. D

11. B

12. $\mathrm{A}$

13. B

14. C

15. A

16. A

17. B

18. D

19. C

20. B

21. B

22. A

23. D

24. D

25. A

26. D

27. A

28. D

29. C

30. A

31. A

32. B

33. C

34. B

35. A

36. D

37. D

38. A

39. C

40. B 